REPORTS OF MORPHOLOGY
Official Journal of the Scientific Society of Anatomists,
Histologists, Embryologists and Topographic Anatomists
of Ukraine
journal homepage: https://morphology-journal.com

\title{
Fractal dimension of external linear contour of human cerebellum (magnetic resonance imaging study)
}

\section{Maryenko N.I., Stepanenko O.Y.}

Kharkiv National Medical University, Kharkiv, Ukraine

\section{ARTICLE INFO}

Received: 12 February 2021

Accepted: 5 April 2021

UDC: $611.817 .1: 57.086: 517: 530.191$

CORRESPONDING AUTHOR

e-mail: maryenko.n@gmail.com Maryenko N.I.
Fractal analysis is a method of mathematical analysis, which provides quantitative assessment of the spatial configuration complexity of the anatomical structures and may be used as a morphometric method. The purpose of the study was to determine the values of the fractal dimension of the outer linear contour of human cerebellum by studying the magnetic resonance images of the brain using the authors' modification of the caliper method and compare to the values determined using the box counting method. Brain magnetic resonance images of 30 relatively healthy persons aged 18-30 years (15 men and 15 women) were used in the study. T2-weighted digital magnetic resonance images were studied. The midsagittal MR sections of the cerebellar vermis were investigated. The caliper method in the author's modification was used for fractal analysis. The average value of the fractal dimension of the linear contour of the cerebellum, determined using the caliper method, was $1.513 \pm 0.008(1.432 \div 1.600)$. The average value of the fractal dimension of the linear contour of the cerebellum, determined using the box counting method, was $1.530 \pm 0.010(1.427 \div 1.647)$. The average value of the fractal dimension of the cerebellar tissue as a whole, determined using the box counting method, was $1.760 \pm 0.006(1.674 \div 1.837)$. The values of the fractal dimension of the outer linear contour of the cerebellum, determined using the caliper method and the box counting method were not statistically significantly different. Therefore, both methods can be used for fractal analysis of the linear contour of the cerebellum. Fractal analysis of the outer linear contour of the cerebellum allows to quantify the complexity of the spatial configuration of the outer surface of the cerebellum, which is difficult to estimate using traditional morphometric methods. The data obtained from this study and the methodology of the caliper method of fractal analysis in the author's modification can be used for morphometric investigations of the human cerebellum in morphological studies, as well as in assessment of cerebellar MR images for diagnostic purposes.

Keywords: fractal analysis, caliper method, box counting method, cerebellum, magnetic resonance imaging.

\section{Introduction}

The human cerebellum has a rather complex spatial configuration, which is the most complex of all the structures of the central nervous system. At the base of the cerebellum is a white substance, which on sagittal and parasagittal sections has a tree-like branched shape. The cerebellar cortex covers the white matter from the outside, repeating the shape of the outer surface of the white matter and forming convolutions - cerebellar folia. Peculiarities of foliation (division of the cerebellar cortex into folia) and fissure of the cortex (delimitation of folia and lobes of the cerebellum by slits) reflect and determine the complexity of the spatial organization of the cerebellum as a whole [22].
In this case, disorders of foliation and fissure of the cortex, arising from disorders of cerebral morphogenesis, is one of the main morphological features of various malformations of the cerebellum [5]. These disorders underlie the classifications of cerebellar malformations and are used as their diagnostic criteria $[5,18,21]$.

In addition, changes in the spatial configuration of the surface of the cerebellar cortex, probably, can be observed in other diseases and pathological conditions. For example, smoothing of the surface of the cortex of the cerebral hemispheres was observed in atrophic changes of the brain $[10,11,12]$, similar changes can be observed in the 
presence of atrophic changes of the cerebellum [6]. However, the characterization of foliation and fissuration of the cerebellar cortex is subjective and descriptive, without defining objective quantitative parameters. Therefore, the search for and development of techniques that could objectively characterize the complexity of the spatial configuration of the surface of the cerebellar cortex is an important area of research in modern neuroscience and morphology.

In recent years, fractal analysis has been increasingly used as a morphometric method. This type of mathematical analysis is used to estimate the complexity of the spatial configuration of different objects. The fractal dimension, which is determined in this case, characterizes the degree of filling of space with a certain object and increases with the complexity of the spatial configuration of this object. Values of fractal dimension, defined on two-dimensional images, vary from 1 to $2[3,4,16]$. For fractal analysis in morphology, neuroscience (including neuroimaging) use different methods of fractal analysis [3, 4, 7, 8, 9, 19], among which the most commonly used methods are box counting $[1,2,10,11,15,23,24]$ and pixel dilatation [14, 17]. The caliper method is also sometimes used [13, 20]. For fractal analysis of various components of the cerebellar tissue most often use the method of box counting [1, 2, 23], less often - pixel dilatation in various modifications [14, 17]. Studies involving fractal analysis of the cerebellum using the caliper method have not been found in the available scientific literature. The method of caliper in the classical version in medicine is rarely used because of its routine. We have developed our own modification of the caliper method, which allows calculations to be performed automatically and more accurately than the classic version. For comparison, we chose the box counting method, which is most often used as a morphometric method in medicine and morphology.

The aim of the study was to determine the values of the fractal dimension of the external linear contour of the cerebellum by examining magnetic resonance imaging of the brain using the author's modification of the caliper method and compare with the values determined using the box counting method.

\section{Materials and methods}

The study was conducted in compliance with the basic bioethical provisions of the Council of Europe Convention on Human Rights and Biomedicine (04.04.1997), the Helsinki Declaration of the World Medical Association on the ethical principles of scientific medical research with human participation (1964-2008), as well as the order The Ministry of Health of Ukraine №690 dated 23.09.2009. The conclusion of the Commission on Ethics and Bioethics of Kharkiv National Medical University confirms that the study was conducted in compliance with human rights, in accordance with current legislation in Ukraine, meets international ethical requirements and does not violate ethical standards for conducting biomedical research (Minutes of the meeting of the commission on ethics and bioethics of KNMU №10 from 07.11.2018).

In study used brain tomograms of 30 relatively healthy individuals (without detected structural changes in the brain) aged 18-30 years, including 15 men and 15 women.

Tomograms were obtained using a magnetic resonance imaging Siemens Magnetom Symphony with a magnetic induction value of $1.5 \mathrm{~T}$. T2-weighted magnetic resonance (MR) images were used for the study. The parameters of magnetic resonance imaging were as follows: TE (echo time) $122 \mathrm{~ms}$, TR (repetition time) 4520 $\mathrm{ms}$, slice thickness - $5 \mathrm{~mm}$. The median sagittal tomographic sections of the cerebellar worm were examined. For fractal analysis, the caliper method in the author's modification and the box counting method in the classical version were used.

Before fractal analysis, pre-processing of magnetic resonance (MR) images of the cerebellum was performed. To do this, a $128 \times 128$ pixel fragment was copied from the digital MR image, which completely contained a tomographic section of the cerebellum (Fig. 1A). Further processing and analysis of images was performed in Adobe Photoshop CS5.

To highlight the outer linear contour of the cerebellum, image segmentation was first performed. The areas of the digital image surrounding the cerebellum (background structures) were painted white (Fig. 1B). After that, the image was converted to binary format (Fig. 1C). The pixels of the binary raster image were of two colours: black (pixel brightness value 0 ; black pixels corresponded to the cerebellar tissue as a whole) or white (pixel brightness value 255; white pixels were background). The halftone image was converted to binary using the Adobe Photoshop CS5 "threshold" tool, which coloured all pixels darker than the specified threshold to black and lighter to white. The brightness thresholds ranged from 100 to 115 and were selected empirically so that the boundaries of the segmented area in the image corresponded to the outer contour of the cerebellar cortex.

After segmentation, fractal analysis was performed using the caliper method in the author's modification. This method included 5 stages. In the first stage of fractal analysis, the segmented area was selected using the "selection" tool of Adobe Photoshop CS5 (Fig. 1D) and the length of the contour (perimeter of the selected area) in pixels was measured using the "analysis" tool.

In the second stage of fractal analysis, a contour with a radius of 2 pixels was smoothed using the tool "selection - modification - smoothing" of Adobe Photoshop CS5 (Fig. 1E). In this case, all bends of the linear contour that had a radius less than the specified value of the smoothing radius were removed from the contour, replaced by a smooth line ("smoothed"). After smoothing, the contour length was measured again.

In the third to fifth stages of the fractal analysis, the 


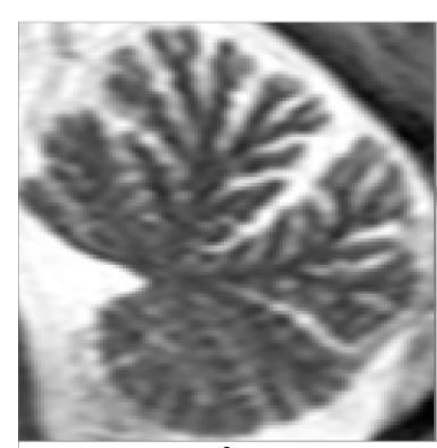

A

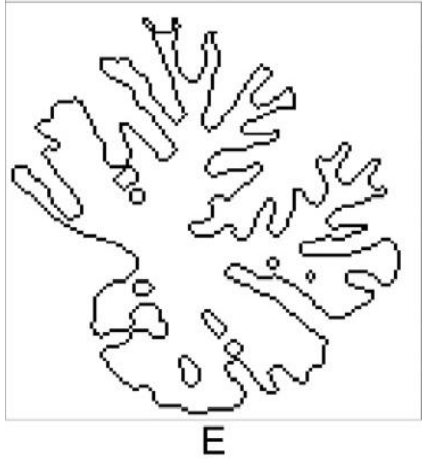

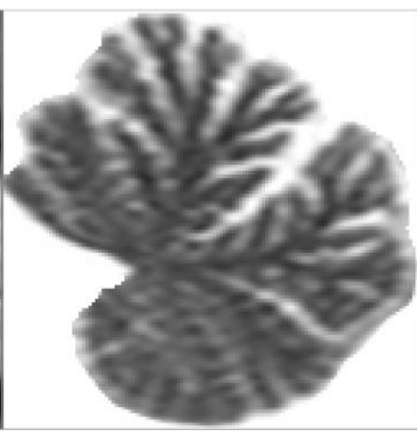

B

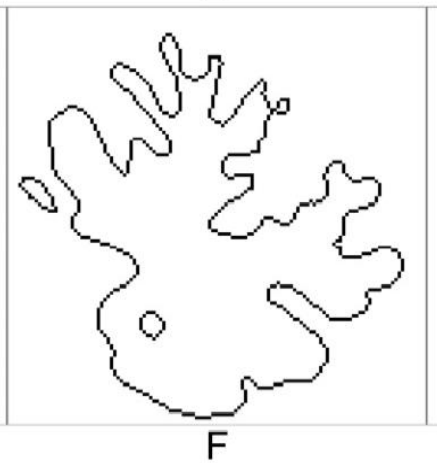

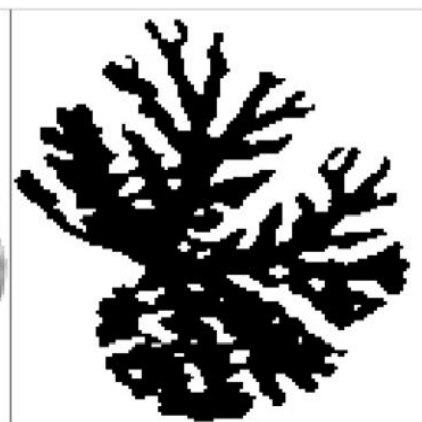

C

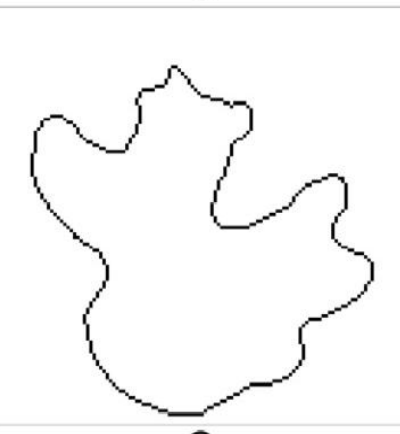

G

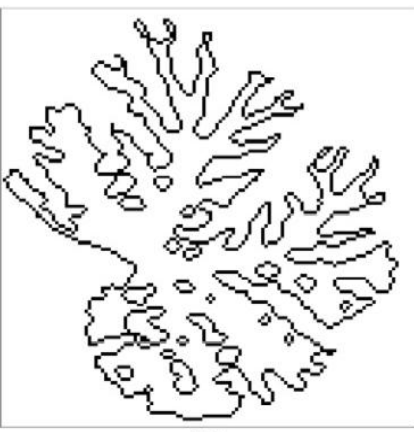

D

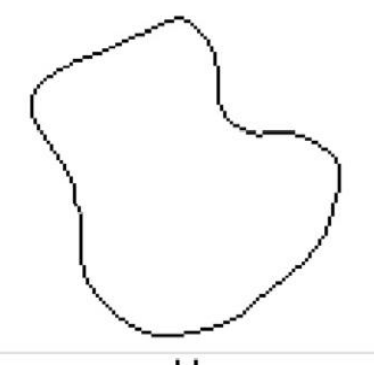

$\mathrm{H}$

Fig. 1. Preliminary processing $(A-C)$ and stages of $M R$ images fractal analysis of the human cerebellum using the method of caliper (D$\mathrm{H}$ ). A - the original image; B - removal of background structures; C - segmented binary image (cerebellar tissue as a whole); D-H - external linear contour of the cerebellum at different stages of fractal analysis: D - 1st stage, contour smoothing is not used; $E$ - 2nd stage, smoothing radius 2 pixels; $F$ - 3rd stage, smoothing radius 4 pixels; $\mathrm{G}$ - 4th stage, smoothing radius 8 pixels; $\mathrm{H}$ - 5th stage, smoothing radius 16 pixels.

contour was smoothed again. In the third stage, the smoothing radius was 4 pixels, in the fourth -8 pixels, in the fifth - 16 pixels (Fig. 1F-H). After each contour modification, the contour length was measured by smoothing it.

Then determined the value of the fractal dimension by the formula:

$$
\mathrm{FD}_{\mathrm{a}}=\frac{\sum_{\mathrm{i}=1}^{5}\left(\operatorname{Ln}_{\left(1 / \mathrm{R}_{\mathrm{i}}\right)}-\overline{\operatorname{Ln}_{(1 / \mathrm{R})}}\right)\left(\operatorname{Ln}_{\left(\mathrm{P}_{\mathrm{i}} / \mathrm{P}_{\mathrm{i}}\right)}-\overline{\mathrm{Ln}_{(\mathrm{P} / \mathrm{R})}}\right)}{\sum\left(\mathrm{Ln}_{\left(1 / \mathrm{R}_{\mathrm{i}}\right)}-\overline{\operatorname{Ln}_{(1 / \mathrm{R})}}\right)^{2}}
$$

where $\mathrm{FD}_{\mathrm{a}}$ is the fractal dimension of the linear contour determined by the caliper method; $\mathrm{R}$ - contour smoothing radius (in pixels); $\mathrm{P}$ - length of the linear contour (in pixels), i - iteration (fractal analysis stage).

Since no smoothing was used in the first stage of fractal analysis, the value of $R_{1}$ was taken as $1\left(R_{1}=1, R_{2}=2, R_{3}=4\right.$, $\mathrm{R}_{4}=8, \mathrm{R}_{5}=16$ ).

To compare the values of the fractal dimension of the linear contour of the cerebellum, determined by the author's modification of the caliper method with the values obtained by classical methods of fractal analysis, also performed fractal analysis using the method of box counting. Image $J$ program was used for this method. Using this program, 2 values of fractal dimension were determined: $F D_{b}$ - fractal dimension of the linear contour of the cerebellum and FD, - fractal dimension of cerebellar tissue as a whole. To determine the $F D_{b}$, we used the contour of the selected area with a line width of 1 pixel (Fig. 1D), and then performed a fractal analysis of the linear contour using the method of box counting. FD values were determined on segmented binary images (Fig. 1C). The following box size values were selected for box fraction analysis in Image $\mathrm{J}: 2,4,8,16,32$ $(1 / 64,1 / 32,1 / 16,1 / 8,1 / 4)$.

To identify factors associated with the values of the fractal dimension of the cerebellum, the following morphometric parameters and their ratio were determined: the length of the contour (perimeter) of the tomographic section of the cerebellum as a whole $\left(P_{0}\right)$, which corresponded to the contour of the visible surface of the cerebellum; the area of the tomographic section of the cerebellum as a whole $\left(\mathrm{S}_{0}\right)$ (Fig. 1B), the length of the contour (perimeter) of the segmented area (Ps) and the area of the segmented area $\left(\mathrm{S}_{\mathrm{s}}\right)$ (Fig. 1C). Based on these data for the tomographic section as a whole and for the segmented area, the values of the form factor $\left(\mathrm{SF}_{0}\right.$ and $\mathrm{SF}_{\mathrm{s}}$ ) were calculated by the formula:

$$
\mathrm{SF}=\frac{4 \pi \times \mathrm{S}}{\mathrm{P}^{2}}
$$

where SF - shape factor, S - area, P - length of the contour (perimeter).

Statistical data processing was performed using Microsoft Excel 2010. For variation series, the following statistical parameters were calculated: arithmetic mean $(M)$, its error $\left(m_{M}\right)$, standard deviation $(\sigma)$ and coefficient of 
variation (CV). To determine the distribution of fractal dimension values, the median (Me), the values of the 25th and 75 th percentiles, the minimum ( $\mathrm{min}$ ) and maximum ( $\max )$ values were determined. The distribution of values for normality was checked using the Shaporo-Wilk W test. The significance of the statistical differences between the three values of the fractal dimension was assessed using the Kruskal-Wallis KW test with multiple Bonferroni correction for multiple comparisons. Pearson's correlation coefficient $(r)$ was calculated to identify and characterize the correlations between the studied parameters. The significance of the correlation was assessed using the Student $\mathrm{T}$ test.

\section{Results}

The average value of $\mathrm{FD}_{\mathrm{a}}$ (fractal dimension of the linear contour of the cerebellum, determined using the caliper method) was $1.513 \pm 0.008$. The minimum value of $F D_{a}$ was 1.432, the maximum - 1.600. The standard deviation was 0.042 , the coefficient of variation was $2.79 \%$, which indicates low variability of fractal dimension values. $\mathrm{FD}_{\mathrm{a}}$ values were distributed normally ( $p>0.05$ ).

The average value of $F D_{b}$ (fractal dimension of the linear contour of the cerebellum, determined by the method of box counting) was $1.530 \pm 0.010$. The minimum value of $\mathrm{FD}_{\mathrm{b}}$ was 1.427 , the maximum - 1.647. The standard deviation was 0.053 , the coefficient of variation was $3.45 \%$, which is slightly higher than the corresponding $\mathrm{FD}_{\mathrm{a}}$, but also indicates the low variability of this value of the fractal dimension. $F D_{b}$ values were also distributed normally $(p>0.05)$.

The average value of $F D_{c}$ (fractal dimension of the cerebellar tissue as a whole, determined by the method of box counting) was $1.760 \pm 0.006$. The minimum value of FD was 1.674, the maximum - 1.837. The standard deviation was 0.030 , the coefficient of variation was $1.73 \%$, which also indicates the low variability of this value of the fractal dimension. FD values were distributed normally $(p>0.05)$. The statistical distribution of $F D_{a}, F D_{b}$ and $F D_{c}$ values is shown in Fig. 2.

The values of the fractal dimensions of the linear contour and the cerebellar tissue as a whole, determined by different methods $\left(F D_{a}, F D_{b}\right.$ and $\left.F D_{c}\right)$ were compared with each other using the Kruskal-Wallis test. When checking the differences between the values of the three fractal dimensions, it was found that the values as a whole were statistically significantly different $(p \approx 0)$.

In a further pairwise comparison of values, it was found that the value of $F D_{c}$, which characterizes the cerebellar tissue as a whole, was statistically significantly different from the two values of the fractal dimension characterizing the linear contour of the cerebellum ( $F D_{a}$ and $\left.F D_{b}\right)(p \approx 0)$. But the two values of the fractal dimension that characterize the linear contour $\left(F D_{a}\right.$ and $\left.F D_{b}\right)$ did not differ statistically significantly $(p>0.05)$. Thus, the values of the fractal dimension of the linear contour of the cerebellum, determined using different methods of fractal analysis (caliper and box counting), had similar values, and the methods gave comparable results. Next, the magnitude of the difference was determined and the relationship between these values of the fractal dimension was investigated.

The difference between the two values of the fractal dimension that characterize the linear contour of the cerebellum $\left(F D_{b}-F D_{a}\right)$, ranged from -0.061 to 0.113 ; the median value of this parameter was 0.014 ; the value of the 25 th percentile was -0.019 ; the value of the 75 th percentile was 0.050 . The value of the difference between the two values of the fractal dimension is associated with a statistically significant strong positive correlation with the value of the fractal dimension of the cerebellar tissue as a whole $\left(F D_{c}\right) \quad(r=0.77, p<0.05)$, a positive correlation of medium strength with the value of the fractal dimension of the linear contour, determined by the method of box counting $\left(F D_{b}\right)(r=0.64, p<0.05)$, and with the area of the segmented area $\left(S_{s}\right)(r=0.54, p<0.05)$. There was no statistically significant correlation with the value of the fractal dimension of the linear contour determined by the caliper $\left(F D_{a}\right)$ method $(r=-0.28, p>0.05)$. In 17 objects out of $30(56.7 \%)$ the value of FDb was higher than FDa.

The ratio of the absolute value of the difference between the two values of the fractal dimension of the linear contour of the cerebellum (|FD $\left.-F D_{a} \mid\right)$ to the arithmetic mean of these two values $\left(\left(F D_{a}+F D_{b}\right) / 2\right)$ varied from $0.07 \%$ to $7.08 \%$; the average value was $2.56 \pm 0.34 \%$. This value is associated with a statistically significant positive correlation of medium strength with the value of the fractal dimension of the cerebellar tissue as a whole $\left(F D_{c}\right)(r=0.60, p<0.05)$,

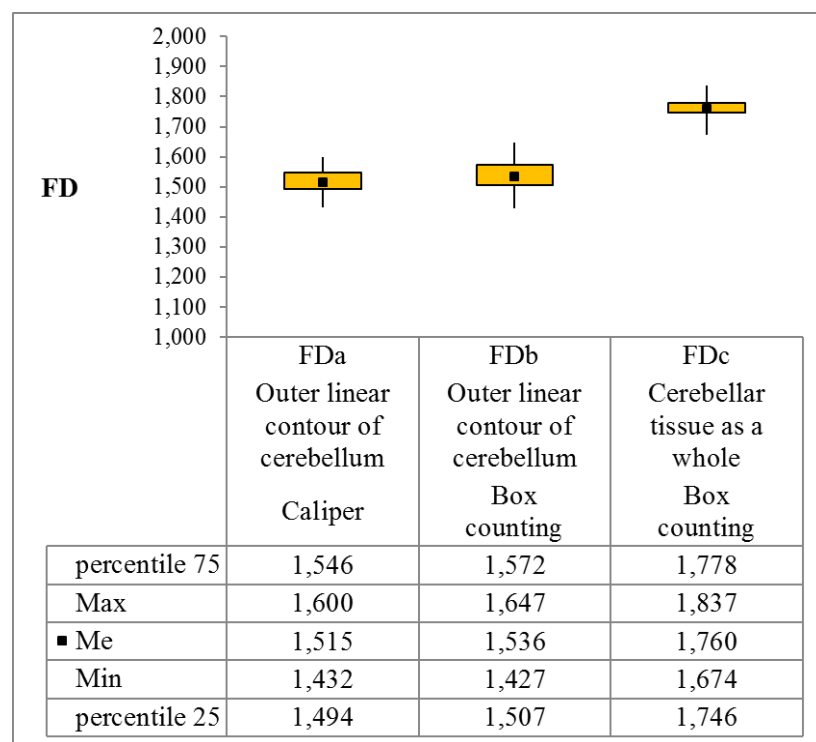

Fig. 2. Distribution of fractal dimensions values of cerebellum external linear contour, determined by different methods of fractal analysis (caliper and box counting) and fractal dimensions of cerebellar tissue as a whole, determined by the method of box counting. 
and with the area of the segmented area $\left(\mathrm{S}_{\mathrm{s}}\right)(\mathrm{r}=0.58, \mathrm{p}<0.05)$, a negative correlation with the value of the fractal dimension of the linear contour, determined by the method of caliper $\left(F D_{a}\right)(r=-0.39, p<0.05)$. No statistically significant correlation was found with the fractal dimension of the linear contour determined by the box counting $\left(F D_{b}\right)$ method $(r=0.24, p>0.05)$.

Therefore, the larger the area of the segmented portion of the image corresponding to the cerebellar tissue as a whole and the greater the fractal dimension characterizing the cerebellar tissue as a whole, the greater the fractal dimension of the linear contour determined by the box counting method exceeded the value determined by using the caliper method and the greater was the difference between these values in general.

When performing correlation analysis, it was found that between the two values of the fractal dimension of the external linear contour of the cerebellum, determined by different methods of fractal analysis $\left(F D_{a}\right.$ and $\left.F D_{b}\right)$, there is a positive correlation of medium strength $(r=0.56, p<0.05)$. No statistically significant correlation was found between FD and $F_{c}$ values $(r=-0.17, p>0.05)$. There is a positive correlation of medium strength between the values of $F_{b}$ and $\mathrm{FD}_{\mathrm{c}}(\mathrm{r}=0.53, \mathrm{p}<0.05)$.

The average value of the ratio of the length of the contour (perimeter) of the tomographic slice as a whole to the area of the slice $\left(\mathrm{P}_{0} / \mathrm{S}_{0}\right)$ was $(0.0358 \div 0.0455, \sigma=0.0027$, $\mathrm{CV}=6.65 \%$ ). The average value of the factor of the shape of the tomographic section as a whole $\left(\mathrm{SF}_{0}\right)$ was $0.69 \pm 0.01$ $(0.56 \div 0.75, \sigma=0.05, C V=6.75 \%)$.

The average value of the ratio of the length of the contour (perimeter) to the area of the segmented area $\left(\mathrm{P}_{\mathrm{s}} / \mathrm{S}_{\mathrm{s}}\right)$ was $0.205 \pm 0.006(0.161 \div 0.271, \sigma=0.031, C V=15.19 \%)$. The average value of the shape factor of the segmented area $\left(\mathrm{SF}_{\mathrm{s}}\right)$ was $0.047 \pm 0.002(0.028 \div 0.076, \sigma=0.012, \mathrm{CV}=24.94 \%)$.

The average value of the ratio of the length of the contour (perimeter) of the segmented area to the length of the contour of the tomographic section as a whole $\left(\mathrm{P}_{\mathrm{s}} / \mathrm{P}_{0}\right)$ was $3.030 \pm 0.060(2.400 \div 3.580, \sigma=0.32, C V=10.69 \%)$. The average value of the ratio of the area of the segmented area to the area of the tomographic section as a whole $\left(\mathrm{S}_{\mathrm{s}} / \mathrm{S}_{0}\right)$ was $0.600 \pm 0.010(0.510 \div 0.740, \sigma=0.050, C V=8.34 \%)$.

A correlation analysis was also performed between the values of fractal dimensions of the cerebellum (FD, $F D_{b}$ and $F D_{c}$ ) and the above morphometric parameters. The values of the correlation coefficient are given in Table 1 .

As can be seen from table 1, the values of the fractal dimension of the outer linear contour of the cerebellum, determined by the method of caliper (FD), are associated with a strong positive correlation with the length of the linear contour $\left(P_{s}\right)$ and the shape factor of the segmented area $\left(\mathrm{SF}_{\mathrm{s}}\right)$, the length of the contour to the area of the segmented area $\left(\mathrm{P}_{\mathrm{s}} / \mathrm{S}_{\mathrm{s}}\right)$, the ratio of the length of the contour of the segmented area to the length of the contour of the tomographic section as a whole $\left(\mathrm{P}_{\mathrm{s}} / \mathrm{P}_{0}\right)$. FD a values are related by a negative correlation of the mean strength with the ratio of the area of the segmented area to the area of the
Table 1. Correlation relationships of fractal dimension values and morphometric parameters of MR images of the human cerebellum.

\begin{tabular}{|c|c|c|c|c|}
\hline \multicolumn{2}{|c|}{ Fractal dimension } & $\mathrm{FD}_{\mathrm{a}}$ & $\mathrm{FD}_{\mathrm{b}}$ & $\mathrm{FD}_{\mathrm{c}}$ \\
\hline \multirow{2}{*}{ Studied object } & \multicolumn{2}{|c|}{$\begin{array}{c}\text { Outer linear contour } \\
\text { of cerebellum }\end{array}$} & $\begin{array}{c}\text { Cerebellar tissue } \\
\text { as a whole }\end{array}$ \\
\hline \multicolumn{1}{|c|}{ Method of fractal analysis } & Caliper & \multicolumn{2}{|c|}{ Box counting } \\
\hline \multirow{4}{*}{$\begin{array}{c}\text { Morphometric } \\
\text { parameters of }\end{array}$} & $\mathrm{P}_{0}$ & 0.244 & 0.252 & $0.354^{*}$ \\
\cline { 2 - 5 } & $\mathrm{S}_{0}$ & 0.176 & $0.388^{*}$ & $0.607^{*}$ \\
\cline { 2 - 5 } & $\mathrm{P}_{0} / \mathrm{S}_{0}$ & -0.084 & -0.347 & $-0.561^{*}$ \\
\cline { 2 - 5 } & $\mathrm{SF}_{0}$ & -0.107 & 0.143 & 0.286 \\
\cline { 2 - 5 } & $\mathrm{P}_{\mathrm{s}}$ & $0.700^{*}$ & $0.705^{*}$ & $0.363^{*}$ \\
\cline { 2 - 5 } & $\mathrm{S}_{\mathrm{s}}$ & -0.301 & 0.223 & $0.782^{*}$ \\
\cline { 2 - 5 } & $\mathrm{P}_{\mathrm{s}} / \mathrm{S}_{\mathrm{s}}$ & $0.857^{*}$ & $0.412^{*}$ & $-0.363^{*}$ \\
\cline { 2 - 5 } & $\mathrm{SF}_{\mathrm{s}}$ & $-0.885^{*}$ & $-0.666^{*}$ & -0.019 \\
\cline { 2 - 5 } & $\mathrm{P}_{\mathrm{s}} / \mathrm{P}_{0}$ & $0.738^{*}$ & $0.745^{*}$ & 0.313 \\
\cline { 2 - 5 } & $\mathrm{S}_{\mathrm{s}} / \mathrm{S}_{0}$ & $-0.648^{*}$ & -0.060 & $0.598^{*}$ \\
\hline
\end{tabular}

Notes: * $-p<0,05$.

tomographic section as a whole $\left(\mathrm{S}_{\mathrm{s}} / \mathrm{S}_{0}\right)$. Correlations between $\mathrm{FD}_{\mathrm{a}}$ and other morphometric parameters were not statistically significant ( $p>0.05)$.

The values of the fractal dimension of the outer linear contour of the cerebellum, determined by the method of box counting $\left(F D_{b}\right)$, are associated with a strong positive correlation with the length of the linear contour of the segmented section $\left(P_{s}\right)$ and with the ratio of the contour length of the segmented section to the total contour $\left(\mathrm{P}_{\mathrm{s}} / \mathrm{P}_{0}\right)$, the positive correlation of the average force with the area of the tomographic section as a whole $\left(S_{0}\right)$ and the ratio of the length of the linear contour to the area of the segmented area $\left(P_{s} / S_{s}\right) . F D_{b}$ values are associated with a negative correlation between the mean force and the segmentation factor $\left(S_{s}\right)$. Correlations between $F_{b}$ and other morphometric parameters were not statistically significant $(p>0.05)$.

The values of the fractal dimension of the cerebellar tissue as a whole, determined by the method of box counting (FD $)$, are associated with a strong positive correlation of medium strength with the area of the segmented area (Ss), a positive correlation of medium strength with the length of the linear contour of the tomographic section as a whole $\left(\mathrm{P}_{0}\right)$ and the segmented area $\left(\mathrm{P}_{\mathrm{s}}\right)$, and with the area of the tomographic section as a whole $\left(\mathrm{S}_{0}\right)$. The FDc values are related by a negative correlation of the mean force with the ratio of the contour length to the area of the tomographic section as a whole $\left(\mathrm{P}_{0} / \mathrm{S}_{0}\right)$ and the ratio of the contour length to the area of the segmented area $\left(\mathrm{P}_{s} / \mathrm{S}_{s}\right)$. Correlations between $\mathrm{FD}_{\mathrm{c}}$ and other morphometric parameters were not statistically significant $(p>0.05)$.

\section{Discussion}

The cerebellum can be considered as a natural fractal object due to the complexity of the spatial configuration, self-repetition and self-similarity of the structure. However, 
studies of the cerebellum using fractal analysis in the available scientific literature are not numerous $[1,2,14$, 23]. During the fractal analysis of cerebellum structures, scientists studied the white and grey matter of the cerebellum [1, 2, 23], or individual branches of the white matter of the cerebellum [14].

In our previous studies, using our own modification of the pixel dilatation method, we determined the values of the fractal dimension of the outer linear contour of the upper and lower cerebellar lobes, which were, respectively, $1.370 \pm 0.009$ and $1.431 \pm 0.008$ [17]. The values of the fractal dimension of the linear contour of the cerebellum obtained in this study slightly exceed these values, because previously only the values of the fractal dimension of individual parts of the cerebellum were determined, in contrast to this study, which studied the linear contour of the cerebellum completely. Differences and features of the studied areas, probably, also cause differences of the received values of fractal dimension.

Other scientists have not previously studied the linear contour of the cerebellum using fractal analysis. Some studies have included fractal analysis of the contour of the cerebral hemispheres (cortex) using the method of box counting, which allowed to quantify the degree of gyrification of the cortex and determine the presence of pathological atrophic changes in the brain $[10,11,12]$. Therefore, the study of the contour of the cerebellar cortex using fractal analysis allows to quantify the spatial configuration of its surface and assess the complexity of the shape of the cerebellum, which is clinically important for diagnosing cerebellar malformations and determining the presence and severity of atrophic cerebellar changes.

For fractal analysis it is important to select the optimal methods and their modifications, as well as the comparability of the results obtained using different methods of fractal analysis. The values of the fractal dimension of the linear contour of the cerebellum, obtained using the methods of caliper and box counting, are very

\section{References}

[1] Akar, E., Kara, S., Akdemir, H., \& Kiris, A. (2015). Fractal dimension analysis of cerebellum in Chiari Malformation type I. Computers in Biology and Medicine, 64, 179-186. https:// doi.org/10.1016/j.compbiomed.2015.06.024

[2] Akar, E., Kara, S., Akdemir, H., \& Kiris, A. (2017). 3D structural complexity analysis of cerebellum in Chiari malformation type I. Medical \& Biological Engineering \& Computing, 55(12), 2169-2182. https://doi.org/10.1007/s11517-017-1661-7

[3] Di leva, A., Esteban, F.J., Grizzi, F., Klonowski, W., \& MartinLandrove, M. (2015). Fractals in the neurosciences, Part II: clinical applications and future perspectives. The Neuroscientist: a Review Journal Bringing Neurobiology, Neurology and Psychiatry, 21(1), 30-43. https://doi.org/ 10.1177/1073858413513928

[4] Di leva, A., Grizzi, F., Jelinek, H., Pellionisz, A.J., \& Losa, G.A. (2014). Fractals in the Neurosciences, Part I: General Principles and Basic Neurosciences. The Neuroscientist: a review Journal Bringing Neurobiology, Neurology and close and do not differ statistically significantly. However, the correlation between these values is lower than expected $(r=0.56)$. This feature can be explained by the very low variability of values: the coefficient of variation of both indicators does not exceed $3.5 \%$. The average value of the difference between the two indicators is $2.5 \%$ and does not exceed $7.5 \%$. Therefore, due to the closeness of the values in the sample, even a small difference between two values of the fractal dimension, determined by different methods of fractal analysis, significantly reduces the correlation between these values.

Therefore, given that the values of the fractal dimension of the linear contour of the cerebellum in the study sample (conditional norm) are distributed in a very small range, and there is no statistically significant difference between the two values of the fractal dimension, the obtained values can be used as normative criteria. using both methods the caliper method in the author's modification and the box counting method.

\section{Conclusions}

1. Fractal analysis of cerebellum outer linear contour allows you to quantify the complexity of the spatial configuration of the outer surface of the cerebellum, which is difficult to assess using traditional morphometric methods.

2. The values of the fractal dimension of cerebellum outer linear contour, determined using the methods of caliper and box counting, are not statistically significant. Therefore, both methods can be used for fractal analysis of the cerebellum linear contour.

3. The data obtained from this study and the method of fractal analysis using the caliper method in the author's modification can be used for morphometric examination of the human cerebellum during morphological studies, as well as to assess the state of the cerebellum on MR images for diagnostic purposes.

Psychiatry, 20(4), 403-417. https://doi.org/10.1177/ 1073858413513927

[5] Demaerel, P. (2002). Abnormalities of cerebellar foliation and fissuration: classification, neurogenetics and clinicoradiological correlations. Neuroradiology, 44(8), 639-646. https://doi.org/ 10.1007/s00234-002-0783-1

[6] Gellersen, H.M., Guo, C.C., O'Callaghan, C., Tan, R.H., Sami, S., \& Hornberger, M. (2017). Cerebellar atrophy in neurodegeneration - a meta-analysis. Journal of Neurology, Neurosurgery, and Psychiatry, 88(9), 780-788. https://doi.org/ 10.1136/jnnp-2017-315607

[7] Grizzi, F., Castello, A., Qehajaj, D., Russo, C., \& Lopci, E. (2019). The Complexity and Fractal Geometry of Nuclear Medicine Images. Molecular Imaging and Biology, 21(3), 401-409. https:/ /doi.org/10.1007/s11307-018-1236-5

[8] Jelinek, H.F., \& Fernandez, E. (1998). Neurons and fractals: how reliable and useful are calculations of fractal dimensions? Journal of Neuroscience Methods, 81(1-2), 9-18. https:// 
doi.org/10.1016/s0165-0270(98)00021-1

[9] John, A.M., Elfanagely, O., Ayala, C.A., Cohen, M., \& Prestigiacomo, C.J. (2015). The utility of fractal analysis in clinical neuroscience. Reviews in the neurosciences, 26(6), 633-645. https://doi.org/10.1515/revneuro-2015-0011

[10] King, R.D., Brown, B., Hwang, M., Jeon, T., George, A.T., \& Alzheimer's Disease Neuroimaging Initiative (2010). Fractal dimension analysis of the cortical ribbon in mild Alzheimer's disease. Neurolmage, 53(2), 471-479. https://doi.org/10.1016/ j.neuroimage.2010.06.050

[11] King, R.D., George, A.T., Jeon, T., Hynan, L.S., Youn, T.S., Kennedy, D.N., \& Dickerson, B. (2009). Characterization of Atrophic Changes in the Cerebral Cortex Using Fractal Dimensional Analysis. Brain Imaging and Behavior, 3(2), 154166. https://doi.org/10.1007/s11682-008-9057-9

[12] Kiselev, V.G., Hahn, K.R., \& Auer, D.P. (2003). Is the brain cortex a fractal? Neurolmage, 20(3), 1765-1774. https:// doi.org/10.1016/s1053-8119(03)00380-x

[13] Lee, K.I., Choi, S.C., Park, T.W., \& You, D.S. (1999). Fractal dimension calculated from two types of region of interest. Dentomaxillofac. Radiology, 28(5), 284-289. doi: 10.1038/sj/ $\mathrm{dmfr} / 4600458$

[14] Liu, J.Z., Zhang, L.D., \& Yue, G.H. (2003). Fractal dimension in human cerebellum measured by magnetic resonance imaging. Biophysical Journal, 85(6), 4041-4046. https://doi.org/ 10.1016/S0006-3495(03)74817-6

[15] Liu, S., Fan, X., Zhang, C., Wang, Z., Li, S., Wang, Y. ... Jiang, T. (2019). MR imaging based fractal analysis for differentiating primary CNS lymphoma and glioblastoma. European Radiology, 29(3), 1348-1354. https://doi.org/10.1007/s00330-018-5658$\mathrm{x}$

[16] Mandelbrot, B.B. (1983). The fractal geometry of nature. N.Y.: W.H. Freeman \& Co.
[17] Maryenko, N., \& Stepanenko, O. (2020). Fractal dimension of phylogenetically different parts of the human cerebellum (magnetic resonance imaging study). Reports of Morphology, 26(2), 67-73. https://doi.org/10.31393/morphology-journal2020-26(2)-10

[18] Patel, S., \& Barkovich, A.J. (2002). Analysis and classification of cerebellar malformations. AJNR. American Journal of Neuroradiology, 23(7), 1074-1087.

[19] Ristanovic, D., \& Milosevic, N.T. (2012). Fractal analysis: methodologies for biomedical researchers. Theoretical Biology Forum, 105(2), 99-118.

[20] Shrout, M.K., Potter, B.J., \& Hildebolt, C.F. (1997). The effect of image variations on fractal dimension calculations. Oral Surgery, Oral Medicine, Oral Pathology, Oral Radiology, and Endodontics, 84(1), 96-100. https://doi.org/10.1016/s10792104(97)90303-6

[21] Soto-Ares, G., Delmaire, C., Deries, B., Vallee, L., \& Pruvo, J.P. (2000). Cerebellar cortical dysplasia: MR findings in a complex entity. AJNR. American Journal of Neuroradiology, 21(8), 1511-1519.

[22] Welker, W.I. (1990). The significance of foliation and fissuration of cerebellar cortex. The cerebellar folium as a fundamental unit of sensorimotor integration. Arch. Ital. Biol., 128(2-4), 87109.

[23] Wu, Y.T., Shyu, K.K., Jao, C.W., Wang, Z.Y., Soong, B.W., Wu, H.M., \& Wang, P.S. (2010). Fractal dimension analysis for quantifying cerebellar morphological change of multiple system atrophy of the cerebellar type (MSA-C). Neurolmage, 49(1), 539-551. https://doi.org/10.1016/j.neuroimage.2009.07.042

[24] Zaletel, I., Ristanovic, D., Stefanovic, B. D., \& Puškaš, N. (2015). Modified Richardson's method versus the box-counting method in neuroscience. Journal of Neuroscience Methods, 242, 9396. https://doi.org/10.1016/j.jneumeth.2015.01.013

\section{ФРАКТАЛЬНА РОЗМІРНІСТЬ ЗОВНІШНЬОГО ЛІНІЙНОГО КОНТУРУ МОЗОЧКА ЛЮДИНИ (ЗА ДАНИМИ ДОСЛІДЖЕННЯ МАГНІТНО-РЕЗОНАНСНИХ ТОМОГРАМ) \\ Мар'єнко Н.І., Степаненко О.Ю.}

Фрактальний аналіз є методом математичного аналізу, який дозволяє кількісно визначити складність просторової конфігурації анатомічних структур та може бути застосований в якості морфометричного методу. Мета дослідження визначити значення фррактальної розмірності зовнішнього лінійного контуру мозочка шляхом дослідження магнітнорезонансних томограм головного мозку за допомогою авторської модифікації способу саliрег та порівняти зі значеннями, визначеними за допомогою способу bох counting. У дослідженні були використані томограми головного мозку зо умовно здорових осіб віком 18-30 років (15 чоловіків та 15 жінок). Досліджували Т2-зважені цифрові магнітно-резонансні зображення. Були досліджені серединні сагітальні томографічні зрізи черв'яка мозочка. Для фррактального аналізу був використаний спосіб caliper в авторській модифікації. Середнє значення фррактальної розмірності лінійного контуру мозочка, визначеної

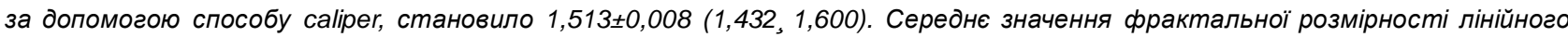

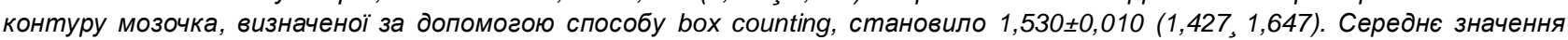

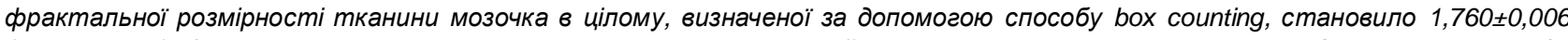
$(1,674 \div 1,837)$. Значення фррактальної розмірності зовнішнього лінійного контуру мозочка, визначені за допомогою способів caliper ma box counting, статистично значуще не відрізняються. Тому обидва способи можуть бути використані для фрактального аналізу лінійного контуру мозочка. Фрактальний аналіз зовнішнього лінійного контуру мозочка дозволяє кількісно оцінити складність просторової конфігурації зовнішньої поверхні мозочка, котру важко оцінити за допомогою традиційних морфометричних методів. Дані, отримані в результаті даного дослідження та методика фрактального аналізу за допомогою способу caliper в авторській модифрікації, можуть бути використані для морфометричного дослідження мозочка людини при проведенні морфологічних досліджень, а також для оцінювання стану мозочка на МР зображеннях із діагностичною метою.

Ключові слова: фрактальний аналіз, спосіб caliper, спосіб box counting, мозочок, магнітно-резонансна томографія. 